\title{
The Development of Teaching Materials to Write Explanatory Text Using an Ecological-Based Flipbook for Grade XI Students at SMA Negeri 1 Padangsidimpuan 2021
}

\author{
Mhd.Hamzah Fansuri Hsb ${ }^{1, *}$ M.Oky Fardian Gafari ${ }^{2}$ Wisman Hadi ${ }^{3}$ \\ ${ }^{1}$ Graduate Student in Indonesian Language and Literature, Universitas Negeri Medan, Medan, Indonesia \\ ${ }^{2}$ Lecturer in the Department of Indonesian Language and Literature, Universitas Negeri Medan, Medan, Indonesia \\ ${ }^{3}$ Lecturer in the Department of Indonesian Language and Literature, Universitas Negeri Medan, Medan, Indonesia \\ *Corresponding author. Email: hamzahhsb3@gmail.com
}

\begin{abstract}
This study aims to produce a teaching material product to write explanatory text using an ecological-based flipbook for grade XI students at SMA Negeri 1 Padangsidimpuan. The method applied in this study was research and development. The results of the needs analysis showed that $100 \%$ of teachers and $90.62 \%$ of students needed teaching materials to write explanatory text using an ecological-based flipbook. Furthermore, the researchers also found that (1) the results of validation from the teaching material experts indicated scores of $82.81 \%$ for teaching material feasibility (very good category), $82.5 \%$ for presentation feasibility (very good category), and $78.84 \%$ for language feasibility (good category), (2) the results of validation from the design experts indicated scores of $85.22 \%$ for visual display (very good category) and $82.95 \%$ for learning design (very good category), (3) the score from teachers' assessment on the developed teaching material was $93.33 \%$ (very good category), (4) the score from the individual trial was $84.72 \%$ (very good category), (5) the score from the small group trial was $90.04 \%$ (very good category), and (6) the score from the limited group trial was $94.33 \%$ (very good category). Apart from that, the score gained by students in writing explanatory text before using an ecological-based flipbook was $63.87 \%$, while the score they gained in writing explanatory text after using an ecological-based flipbook was $79.96 \%$.
\end{abstract}

Keywords: teaching materials, explanatory text, ecology, flipbook.

\section{INTRODUCTION}

Learning is an activity that involves a person, two parties, or more that creates a learning process. During the learning process in a formal environment, such as school, teachers strive for students to acquire knowledge, skills, and positive values. To achieve learning objectives that are in line with expectations, teachers are required to be able to develop teaching materials according to current development in order to achieve learning objectives.

Developing teaching materials must be carried out as an effort to improve learning outcomes and adjust the applied teaching materials with the context of the situation at school. Teachers as educators are tasked with managing and developing learning resources as stipulated in Indonesia's National Education System
Law No.20/2013 article 39, namely "education personnel are tasked with carrying out administration, management, development, supervision, and technical services to support the educational process in educational units."

Indonesian language subjects in the 2013 curriculum are text-based learning, prioritizing the activeness of students, mastery of knowledge, and skills of students in writing a text. An example of language and literary aspects in this curriculum is explanatory text writing skills for grade XI students, as set in basic competence points 3.4 (analyzing the structure and language aspects of the explanatory text) and 4.4 (making explanatory texts orally or in writing by paying attention to structure and language aspects).

Explanatory text is a type of text that contains explanations about the process of occurrence of an 
event, such as natural events, cultural events, and social events. Therefore, in learning explanatory texts, students are inseparable from the topic of "ecology". In relation to literary studies, the term ecology is used in various meanings. The first is the term "ecology" used in a limited sense in the context of natural ecology. Studies of ecology in this first meaning are also known in two forms, namely ecological studies emphasizing natural aspects as inspiration for literary works and ecological studies emphasizing defense or advocacy of environmental damage caused by human actions. The second is the term "ecology" used in the sense of cultural ecology which is determined by the pattern of life and differences in regional characteristics.

The development of information and communication technology has brought changes to the world of education. As a process that has been developed, information and communication technology can affect the understanding of knowledge from the aspect of multimedia applications to improve the quality of education. Media is a tool in the teaching and learning process. Media is used to convey messages and information. One of the media which can fulfill this purpose is Kvisoft FlipBook Maker. This is an application to create e-books or e-magazines. Not only providing text-based form, but this application can also insert images, graphics, sound, links, and videos in the generated e-books. An e-book (electronic book) is a digital book stored in an electronic application so that it can be opened using a computer or other device designed for learning purposes. Since 2019 to date, there has been a pandemic called COVID-19. This pandemic has damaged the world of education and has shifted the learning system from offline learning to online learning. For this reason, Kvisoft FlipBook Maker is very helpful for teachers and students for maximizing the teaching and learning process.

\section{METHOD}

The type of this study was research and development $(\mathrm{R} \& \mathrm{D})$. The development procedures carried out in this study were (1) analyzing the problems and needs, (2) carrying out development planning, (3) developing initial products, (4) doing expert validation, (5) following up the revisions, (6) conducting product trials, (7) following up the product revisions, (8) doing product improvement, and (9) carrying out mass production. In this study, the data were collected using questionnaires consisting of expert validation questionnaires and teacher \& student responses questionnaires. The study was carried out in class XI (selected randomly) of SMA
Negeri 1 Padangsidimpuan during the odd semester of 2020/2021.

\section{RESULTS AND DISCUSSION}

At the initial validation stage, two Indonesian language teachers $(100 \%)$ stated that they applied teaching materials to teach writing explanatory text. Besides, 32 students $(100 \%)$ stated that they received lessons from teaching using teaching materials in the topic of writing explanatory text. In addition, teachers and students (100\%) stated that they had not applied ecological-based teaching materials to write explanatory text. Teachers $(100 \%)$ stated that they needed teaching materials to teach students in writing explanatory text in the form of an ecological-based flipbook. Meanwhile, 29 students $(90.62 \%)$ also stated that they needed teaching materials in writing explanatory text in the form of an ecological-based flipbook

\subsection{Data of Needs Analysis}

\begin{tabular}{|c|c|c|c|c|c|c|}
\hline \multirow[b]{2}{*}{ No } & \multirow[b]{2}{*}{ Questions } & & \multicolumn{4}{|c|}{ Frequency } \\
\hline & & $\begin{array}{l}\text { Ans } \\
\text { wer }\end{array}$ & $\begin{array}{l}\mathrm{T} \\
\mathrm{e} \\
\mathrm{a} \\
\mathrm{c} \\
\mathrm{h} \\
\mathrm{e} \\
\mathrm{r}\end{array}$ & $\%$ & $\begin{array}{l}\mathrm{S} \\
\mathrm{t} \\
\mathrm{u} \\
\mathrm{d} \\
\mathrm{e} \\
\mathrm{n} \\
\mathrm{t}\end{array}$ & $\%$ \\
\hline \multirow[b]{2}{*}{1} & \multirow{2}{*}{$\begin{array}{l}\text { The presence } \\
\text { of teaching } \\
\text { materials to } \\
\text { write } \\
\text { explanatory } \\
\text { texts }\end{array}$} & Yes & 2 & $\begin{array}{c}100 \\
\%\end{array}$ & $\begin{array}{l}3 \\
2 \\
\end{array}$ & $\begin{array}{c}100 \\
\%\end{array}$ \\
\hline & & No & 0 & $0 \%$ & 0 & $0 \%$ \\
\hline \multirow[b]{2}{*}{2} & \multirow[b]{2}{*}{$\begin{array}{l}\text { Using } \\
\text { ecological- } \\
\text { based } \\
\text { teaching } \\
\text { materials to } \\
\text { write } \\
\text { explanatory } \\
\text { texts }\end{array}$} & Yes & 0 & $0 \%$ & 0 & $0 \%$ \\
\hline & & No & 2 & $\begin{array}{c}100 \\
\%\end{array}$ & $\begin{array}{l}3 \\
2\end{array}$ & $\begin{array}{c}100 \\
\%\end{array}$ \\
\hline \multirow[b]{2}{*}{3} & \multirow{2}{*}{$\begin{array}{l}\text { Demanding } \\
\text { teaching } \\
\text { materials in } \\
\text { the form of an } \\
\text { ecological- } \\
\text { based flipbook } \\
\text { to write } \\
\text { explanatory } \\
\text { texts }\end{array}$} & Yes & 2 & $\begin{array}{c}100 \\
\%\end{array}$ & $\begin{array}{l}2 \\
9 \\
\end{array}$ & $\begin{array}{l}90.6 \\
2 \% \\
\end{array}$ \\
\hline & & No & 0 & $0 \%$ & 3 & $\begin{array}{c}9.37 \\
\%\end{array}$ \\
\hline
\end{tabular}


The results presented in the table above indicate that students and teachers need teaching materials in form of an ecological-based flipbook in the teaching and learning process concerning writing explanatory text.

The process of developing a teaching material product to write explanatory text using an ecologicalbased flipbook for grade XI students was carried out in four stages. In the first stage, the researchers carried out the needs analysis for teachers and students. After that, the researchers set the instructional objectives, consisting of basic competencies, indicators of competency achievement, learning objectives, and the scope of the teaching materials. In the second stage, the researchers designed the teaching material. In general, the developed teaching material to write explanatory text using an ecological-based flipbook contained the following points: (1) colored cover, (2) preface, (3) table of contents, (4) core competencies, (5) basic competencies \& indicators, (6) learning materials, (7) practice, (8) final task, and (9) bibliography. In the third stage, the developed teaching material went through a transforming process into an electronic book with the following stages: (1) made in Microsoft Word format, (2) converted into Acrobat Reader DC (PDF) format, and (3) processed using Kvisoft FlipBook Maker application (add file-page edit-design-publish).

In the fourth stage, the developed teaching material is assessed. The validation was carried out by 2 design experts, 2 teaching material experts, and 2 Indonesian language teachers. Furthermore, the developed teaching material was tested on students. The validation carried out by teaching material experts covered three aspects of feasibility, namely teaching material feasibility, presentation feasibility, and language feasibility. The aspect of teaching material feasibility consisted of three points, namely (a) the suitability of the teaching material with basic competence, (b) the accuracy of the teaching material, and (c) the quality of the teaching material. The obtained average score for all points of teaching material feasibility was in the "very good" category with a total percentage of $82.81 \%$. The aspect of presentation feasibility also consisted of three points, namely (a) the technique of presentation, (b) learning presentation, and (c) completeness of presentation. The obtained average score for all points of presentation feasibility was in the "very good" category with a total percentage of $82.5 \%$. For the aspect of language feasibility, the developed teaching material had met the demands of the learning process. The obtained score for language feasibility was in the "good" category with a percentage of $78.84 \%$.

Apart from that, the validation carried out by design experts covered two aspects: visual display and learning design. The results of the evaluation in the aspect of visual display indicated that the developed teaching material has met the demands of the learning process. The score for this aspect was in the "very good" category with a percentage of $85.22 \%$. The results of the evaluation in the aspect of learning design also indicated that the developed teaching material has met the demands of the learning process. The score for this aspect was in the "very good" category with a percentage of $82.95 \%$. Furthermore, after being assessed by the teachers, the developed teaching material to write explanatory text using an ecological-based flipbook was declared to have met the demands of the learning process. The obtained average score from teachers' assessment on the developed teaching material to write explanatory text using an ecological-based flipbook was in the "very good" category with a percentage of $93.33 \%$.

The obtained score at the individual trial stage on the developed teaching material to write explanatory text using an ecological-based flipbook was in the "very good" category with a percentage of $84.72 \%$. Individual trials were carried out to determine students' initial responses and to identify deficiencies in the developed product prior to small group trials. The obtained score at the small group trial stage on the developed teaching material to write explanatory text using an ecologicalbased flipbook was in the "very good" category with a percentage of $90.04 \%$. This stage was carried out after following up the deficiency found in the individual trial so that the assessment instrument was revised, especially concerning the composition of the teaching material and the use of language that was easier for students to understand. The obtained score from the limited group trial on the developed teaching material to write explanatory text using an ecological-based flipbook was in the "very good" category with a percentage of $94.33 \%$.

\subsection{Results of Product Trial}

This trial was carried out after following up the deficiency found in the small group trial so that the assessment instrument was revised, especially concerning the composition of the teaching material and the use of language that was easier for students to understand. 


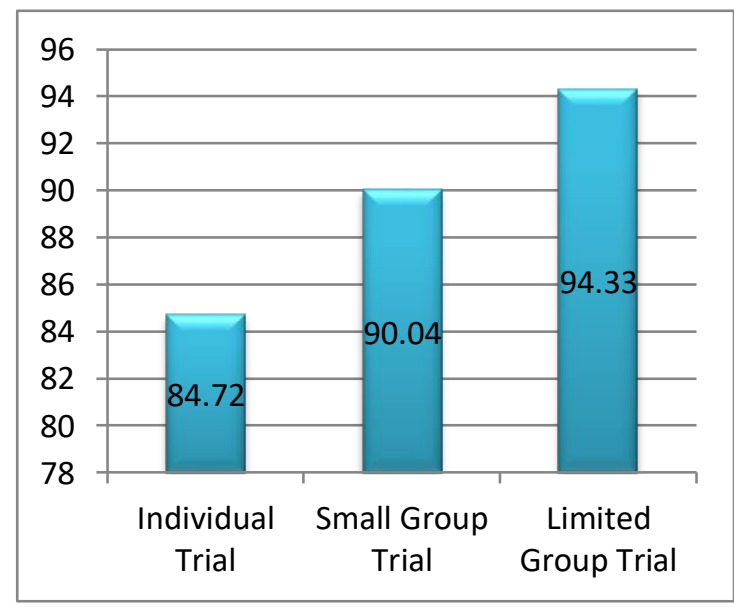

The learning outcome of students concerning making explanatory texts before the implementation of the teaching materials in the form of an ecologicalbased flipbook was $63.87 \%$. Meanwhile, the learning outcome of students concerning making explanatory texts after the implementation of the teaching materials in the form of an ecological-based flipbook was $79.96 \%$. The difference was $16.09 \%$ from before and after using the teaching materials in the form of an ecological-based flipbook.

\section{CONCLUSION}

The developed teaching material to write explanatory text using an ecological-based flipbook for grade XI students at SMA Negeri 1 Padangsidimpuan was classified in the "good/valid" category. Teachers and students enjoyed the developed teaching material. Furthermore, the results of trials and validation from teaching material experts, design experts, lecturers, teachers, and students indicated that this developed teaching material can be applied in the school.

\section{REFERENCES}

[1] Anggun Melati Sari, Sarwiji Suwandi, Atikah Anindyarini. Universitas Sebelas Maret. Peningkatan Motivasi Belajar Dan Keterampilan Menulis Teks Eksplanasi Kompleks Melalui Metode Kooperatif Tipe Picture and Picture Pada Siswa SMK. BASASTRA Jurnal Penelitian Bahasa, Sastra Indonesia danPengajarannya Volume 3 Nomor 3, Agustus 2015, ISSN I23026405.
[2] Arifin, Zainal. 2009. Evaluasi Pembelajaran. Bandung: PT Remaja Rosda Karya.

[3] Arsyad, Azhar. 2017. Media Pembelajaran Edisi Revisi. Jakarta: Rajawali Press.

[4] Dony Sugianto, Ade Gafar Abdullah, Siscka Elvyanti, Yuda Muladi. Program Studi Pendidikan Teknik Elektro, Fakultas Pendidikan Teknologi dan Kejuruan Universitas Pendidikan Indonesia, Modul Virtual: Multimedia Flipbook Dasar Teknik Digital, Invotec, Volume IX, No.2, Agustus2013: 101-116

[5] Kementrian Pendidikan dan Kebudayaan. 2017. Bahasa Indonesia Ekspresi Diri dan Akademik. Jakarta: Kementerian Pendidikan dan Kebudayaan.

[6] Khaerunnisa. Universitas Muhammadiyah Jakarta.Penerapan Model Discovery Learning Berbantuan Media Audiovisual Terhadap Keterampilan MenulisTeks Eksplanasi (Penelitian Tindakan Pada Siswa Kelas XI di SMA Dharma Karya Ut Kota Tangerang Selatan). Lingua Franca: Jurnal Bahasa, Sastra, dan Pengajarannya $P$ ISSN: 2302-5778 Vol 6 No. 2 Agustus 2018 Hal 71 - 81E-ISSN: 2580-3225 Vol 2 No. 2 Agustus 2018 Hal $71-81$

[7] Moch.Saleh. Peningkatan Kemampuan Menulis Teks Eksplanasi Komplek Melalui Model Stad Pada Siswa SMA. BRILIANT: Jurnal Riset dan Konseptual Volume 1 Nomor 1, November 2016

[8] Novita Andyani, Kundharu Saddhono, YantMujyanto. FKIP Universitas Sebelas Maret. Peningkatan Kemampuan Menulis Teks Eksplanasi Dengan Menggunakan Media Audiovisual Pada Siswa Sekolah Menengah Pertama. BASASTRA Jurnal Penelitian Bahasa, Sastra Indonesia dan Pengajarannya Volume 4 Nomor 2, Oktober 2016, ISSN I2302-6405

[9] Nurwahyuni Sukmawati. Mahasiswa Magister Pendidikan Bahasa Indonesia. Pengembangan Flip Book Teks Eksplanasi Kompleks Untuk Peserta Didik Kelas XI SMA/ MA Semester 2. NOSI Volume 4, Nomor 3, Agustus 2016 Jurnal PPS Universitas Islam Malang.

[10] Ntobuo E. N. dkk. 2018. The Development of Gravity Comic Learning Media Based on Gorontalo Culture.JPII 7 (2)246-251 
[11] Sugiyono. 2016. Metode Penelitian Pendidikan kuantitatif, Kualitatif, dan $R \& D$. Bandung: Alfabeta.

[12] Ulfah, Warniatul. 2017. Pengembangan Bahan Ajar Menulis Teks Eksplanasi Berbasis Pengalaman Pada Siswa Kelas XI SMA Negeri Unggul Aceh Timur. Tesis.Universitas Negeri Medan 